HStud 23 (2009)1, 59-76

DOI: 10.1556/HStud.23.2009.1.6

\title{
POLITICS AND LITERATURE: A CASE STUDY
}

\author{
KOSZTOLÁNYI’S RECEPTION DURING THE COMMUNISM
}

ZSUZSANNA ARANY

\author{
HAS-ELTE Critical Editions Research Group, Budapest \\ Hungary
}

\begin{abstract}
As a contribution to a larger theoretical discussion of the relationships between literature and political context, this paper offers an examination of the reception of the works of Hungarian poet and novelist Dezső Kosztolányi during the communist period, drawing particular emphasis to the origins of several misunderstandings. Over the past several decades Hungarian Marxist literary theorists, influenced by the philosophical and aesthetical heritage of György Lukács, have thought of artists as having a revolutionary role in society and literature as having an important role as a means through which to educate the nation. Kosztolányi's concept of art for art's sake did not minister to this ideological and political system, and as a consequence his reception and reputation suffered. Not only were critical evaluations of his writings, both literary and theoretical, distorted and crafted with the intention of creating a misleading image of the author, but the editions of his texts were also censored. It is not mere accident or circumstance that the critical edition series of his works could not be edited and research groups and projects dealing with an edition of his life's work were not financed under the communist regime. Hungarian intellectuals have yet to raise the question as to why open discussion of the beginning of the 20th century (when events took place that continue to exert an influence on conceptions of culture today) remains a taboo. Why are there no (or few) critical editions and anthologies or studies dealing with the period? Twenty years have passed since the political transition and the situation remains essentially the same. Hungarian philologists who deal with Kosztolányi's oeuvre must address these questions and challenge the Marxist axioms and stereotypes if they hope to further the development of Kosztolányi's reception. Relying on postmodern theories is not sufficient if there is little fundamental research.
\end{abstract}

Keywords: commune, Dezső Kosztolányi, György Lukács, literary canon, Hungarian literature, art for art's sake, literature, politics, Marxism, reception history

The interrelationships between politics and literature raise difficult questions. Politics is the domain of mundane power, laws and societies, while literature is the domain of intellectual and aesthetic values in their relation to consciousness. Nevertheless literature becomes subject to the play of public power, and its shaping role is directed towards the collective and individual mind. In line with this, litera- 
ture responds to relations of cultural policy in the values it projects and the institutions and leading figures that serve it. We are perhaps better able to begin formulating answers to the questions of the interrelationships between politics and literature if we proceed with the analysis of an individual writer and the reception of his works, rather than dealing with the subject from a purely theoretical point of view. As a contribution to this larger discussion, I offer the following examination of the reception of the works of Hungarian poet and novelist Dezső Kosztolányi during the communist period, drawing particular emphasis to the origins of some misunderstandings.

Many theorists argue that literature (and indeed art in general) is free from political aspects, in accordance with the idea of art for art's sake. As Perez Zagorin argues in the foreword of his book on culture and politics,

\begin{abstract}
L'art pour l'art (though even this phenomenon is hardly immune from the political) did not exist. Statesmen, ministers, and political men formed a comparatively small elite with many relations to writers great and small, philosophers, and artists, Popular and radical protest movements usually reflected their own distinctive cultural aspirations and identity. ${ }^{1}$
\end{abstract}

Kosztolányi also wrote essays on the question of the role of literature in society and whether literature itself should apostolate revolutionary programs for the public or remain independent. Most of his reviewers do not merely analyze his literary works, but rather take issue with his aesthetical statements. And subsequent upon these kind of comments the figure of the author himself and indeed his entire oeuvre becomes distorted. But we have to raise another question: are there any commentaries that might offer an image of the author that could be thought of as real? Indeed is this possible at all?

Over the past several decades Hungarian Marxist literary theorists have thought of artists as having a revolutionary role in society. An artist should be a sort of light in the darkness and should conduct himself as a prophet. Literature also has an important role in accordance with this idea as a means through which to educate the nation. It is for this reason that elements of art that do not serve this ideology were excluded during the communist period in Hungary. Kosztolányi's concept of art for art's sake did not minister to this ideological and political system. Essays on the theory of independent art were understood as being in opposition to the political and educational task of literature. Not only were the critical evaluations of Kosztolányi's writings, including literary and theoretical, distorted and crafted with the intention of creating a misleading image of the author, but the editions of his texts were also censored. It is not mere accident or circumstance that the critical edition series of his works could not be edited and research groups and projects dealing with the lifework edition were not financed under the com- 
munist regime, and indeed this remains a thorny literary (and political) question today.

Ideologies always have an effect on broader society. The famous Marxist philosopher György Lukács wrote in one of his studies,

The duty of the literate is different. It is to keep the real questions of Hungarian national life alive and make them known, and search for and find the progressive answers to them. Achievement of that great task determines the responsibility of the literate. ${ }^{2}$

Since some of Kosztolányi's poems and novels are obligatory reading at secondary grammar schools in Hungary and the reception of his works creates an articular part of contemporary literary and humanist life, the oeuvre acquires an additional function in the education of the nation and the definition of the role of literature, becoming part of the cultural and educational institutional system. The Kosztolányi question is an emblematic ideological problem as well, since both addressing it or keeping silence on it can function as an instrument of an oppressive (political) apparatus.

The history of the reception of Kosztolányi's oeuvre can be divided into several parts. As we are dealing mostly with interpretive communities and groups or schools that inherited one another's points of view, these groups created the determining opinions and interpretations of the image of Kosztolányi. Their functions were temporarily limited, so we can speak about distinct periods. These schools represent different ideologies as well. One could pose the question: can a clear image of Kosztolányi exist at all? I have no intention of posing as an omniscient interpreter, but merely wish to point out how politics and ideology influence literature and literary history in the 20th century in Hungary through this example.

The theorist György Lukács, who was one of the leading figures in the past decades of Hungarian literary and cultural life, argues in his early writings that interpretations of literature have connections with social life as well. According to his argument education and interpretation can influence common attitudes and conceptions of thought. In 1919 Lukács started to deal with Marxist thoughts. As Tibor Hanák notes in his work on Lukács, this was a political turn, not a philosophical one,

In the articles that he wrote during the Commune of 1919 he [Lukács] sees in the revolution only the potential for moral cleansing and cultural advances; at the time he professes, 'politics is only a tool, culture is the goal'. His decision to join the communists did not mean the discovery of redemptive doctrine, nor was it an ideological commitment [...] In the late autumn of 1918 György Lukács [...] simply made a political volte-face. ${ }^{3}$ 
Paul de Man also rejects the argument that one can make a distinction between the early and the later periods of Lukács' work. Instead of a Marxist turn he discerns a kind of continuity, and readers can find marks of the romanticist and idealist heritage in his later works as well,

\begin{abstract}
The weaknesses of the later work are already present from the beginning, and some of the early strength remains operative throughout. Both weakness and strength, however, exist on a meaningful philosophical level and can only be understood in the larger perspective of nineteenth and twentieth-century intellectual history: they are part of the heritage of romantic and idealist thought. ${ }^{4}$
\end{abstract}

In time the Marxist trend becomes more particular in Lukács's texts. While Western tradition puts emphasis on the Hegelian basis of his ideas, the Hungarian reception focuses mostly on Marxist elements. This problem becomes essential in the discussion of the reception of the works of Kosztolányi.

Because of the decisive influence of the ideas of Lukács, the image of Kosztolányi that we have inherited is a distorted one. Lukács was one of Kosztolányi's contemporaries, and during the 1910s and 1920s they had personal conflicts in addition to their theoretical disagreements. Before World War I Kosztolányi published articles in Marxist periodicals such as Népszava and Világ, the latter of which was the official paper of the Hungarian freemasons and was edited by Oszkár Jászi and Lajos Purjesz. After the Commune of 1919 he became a contributor to Új Nemzedék, which was one of the main organs of governor Horthy during the period referred to by some historians as the White Terror. ${ }^{5}$ While Lukács was minister of education during the Commune of $1919,{ }^{6}$ Kosztolányi became the editor of the column entitled Pardon, which gibbeted the leaders and followers of the four-month communist reign and which constituted an instrument (or weapon) in the hands of the governor during the white terror. But the antagonism between Kosztolányi and Lukács began before the appearance of Miklós Horthy. Lukács attacked Kosztolányi because of an editorial published on May 8th, 1919 in Pesti Napló. The article, entitled Beer úr (Sir Beer), was about the talks in Paris that concluded with the Treaty of Trianon, and it struck something of a nationalistic tone. ${ }^{7}$ Due to this affair Lukács and the other leading political figures of the Commune not only advanced against Kosztolányi, but started to work out regulations and rules for controlling the media. According to a document entitled Forradalomban (In the Revolution), part of a collection of documents on Lukács's role in the Commune,

the history of the conflicts between the media and Lukács, or rather the Ministry of Education, includes the earlier order of the Ministry that editorials in bourgeois daily periodicals be published with the signatures of the authors. In his book entitled Vallomások (Confes- 
sions), Ferenc Göndör [who emigrated to Vienna after the Commune] attributes the order, which was issued in the beginning of May [1919], to Lukács. One finds only a single remark in the media of the Commune concerning this in an editorial by Pál Hajdu printed in Vörös Újság (Red News) on May 9th [...] The article was a shrill attack on 'the slothful caste of journalists, who had degenerated into a class above classes.' This attack had been brought about by the publication in the media of the bourgeois citizenry of several articles commenting in a nationalistic tone on military and economic steps that had been taken against the commune and that had provoked the ire of the communist leaders. (The editorial Beer úr, published on May 8th in Pesti Napló, was among the problematic articles. $)^{8}$

The minute books of the discussions on the media during the communist dictatorship in 1919 make apparent that journalists had to face difficult existential questions. The media law came into existence on May 14th, which meant unemployment for most of the members of the press. ${ }^{9}$

During the Commune of 1919 politicians established an organization for writers led by Ernő Osvát. Lukács validated the organization, which determined whether a manuscript would be published or not. The situation was similar after World War II, when the Writers' Union was established. As George F. Cushing argues,

At first this was a democratic forum, but it soon became a tool in the hands of the Communist Party to secure conformity. Writers who had never before submitted to direct control and who in any case inherited the traditions of opposition showed considerable reluctance to tow the Party line. ${ }^{10}$

Lukács talked about artistic aspects, not political issues, but books that promoted Marxist and communist ideas were favored. Furthermore, as may seem apparent in retrospect, artistic aspects were defined as artistic from a Marxist point of view. Books that represented theories of art for art's sake were not given priority in publishing. As is common knowledge, in the later period other communists took issue with Lukács's ideas. Other political leaders of the Commune asked him about his Hegelian and romanticist viewpoints. As Tibor Hanák, the emigrant Hungarian theorist, observes,

Lukács did not turn his back on the Hegel question, even after his self-criticism in 1934. In 1938 he completed his manuscript on the youth of the idealist German philosopher, which however he was not able to publish in the Soviet Union because of the ruling official school of thought [...] In [Lukács'] opinion, Hegel's analysis of intellectual development and a close attentiveness to the formation of idealist dialectics constituted an inseparable part of the genesis of Marxist dialectics. ${ }^{11}$ 
Lukács, who himself was a literary theoretist, liked to speak about Kosztolányi with a negative overtone, not simply about his works, but about his personality and his political role in 1919-1920, which all comprised the focus of several of his essays. In an essay published in Huszadik Század in 1907 he ranked Kosztolányi behind Ady, though he admired his poetic talent, commenting that

\begin{abstract}
Dezső Kosztolányi [...] is the only lyricist since Ady who is worth attention [...] Endre Ady was the poet of the combative Hungarian intellectuals; Kosztolányi was an aesthete [...] Kosztolányi’s significance is that he can see everything that the best among our painters see, and often is able to find words for this. If there were a few more poets like him, searching with such intense effort for the new Hungarian language, in ten years one would be able to write anything in Hungarian. ${ }^{12}$
\end{abstract}

Most of the later interpretations on Kosztolányi, which were founded on Lukács' ideology, contain the condemnation of his role in 1919-1920 as part of Uj Nemzedék, even if these writings show appreciation for his literary works. This reveals that the key issue in the history of Kosztolányi's reception is its origins in the writings and ideas of Lukács (which relate to personal and historical aspects), his editorship of Pardon in 1919-1921, and the conflict with Ady's ideological and artistic heritage in 1929.

Journalists had to struggle amidst the changes of regime following World War I (first the Commune, then the so-called White Terror of Miklós Horthy) to survive professionally. Due to the rapid pace of change they were often only able to get work alternately at periodicals the editorship of which bore differing political views. Employment was frequently merely an existential question. This practical explanation notwithstanding, the reception of the writings of authors who worked as journalists characterized this as symbolic of a lack of principles. It interesting that most of the interpreters only put emphasis on the activities of Kosztolányi and forgot to mention figures such as Emma Ritoók, who before World War I had been a member of the group of Marxist artists and theorists (Lukács and Béla Balázs among them) known as the Vasárnapi Kör (Vasárnap Circle). After the Commune she also became an author of Új Nemzedék, the leading newspaper of the Horthy regime. But one might also mention János Komáromi or Kálmán Harsányi, and it is worth noting that during the White Terror most of the leftist papers, such as Népszava, were censored, which rendered it more difficult to find a job as a journalist.

The question of whether the writers and artists who played cultural roles in the Commune of 1919 did so under pressure or not remains open in many cases to this day. Whether the writers, Kosztolányi among them, were obliged to deal with Marxist theories or whether they chose to is uncertain. The translation of the most celebrated works of Karl Marx constituted an important project of the Com- 
mune's cultural policy. This required well-educated and talented writers who could prepare the translations. Sources concerning this, however, are contradictory. In one of his late interviews Lukács names Kosztolányi as an enthusiastic translator of Marx, and given this he brands Kosztolányi's behavior during the White Terror as shameful. Since Lukács exercised a considerable influence on the cultural policy of the Commune, his assertions remain suspicious. As a leading figure and a person responsible for the decisions made at the time, his reminiscences are hardly independent or objective, a fact that one should keep in mind when reading his recollections,

Mikszáth's notion, expressed in the line 'Show me a government that I will not support,' was pertinent under the dictatorship as well. I need mention only one example: Dezső Kosztolányi offered to organize a team to translate Marx's Capital. Nobody put pressure on him, on the contrary it was very difficult to dissuade him from undertaking his plan [...] We must not, for the purpose of idealization, omit from the history of the dictatorship the fact that people like Kosztolányi presented themselves en masse. In that situation my standpoint was that I did not take Kosztolányi's decision seriously, but I would have thought it ridiculous had the dictatorship not taken advantage of these possibilities. Subsequently people spoke about compulsion. Even Kassák talked about this later on, when he wanted to flatter the right-leaning social democrats. ${ }^{13}$

In contrast, several articles printed in the re-launched Új Nemzedék, which was also banned during the Commune, detail the sufferings of the red terror. Since that daily was owned by the Központi Sajtóvállalat (Central Media Firm) and was close to the circle of Horthy, these texts must also be read critically, as their authors were not in a position to write with a clear measure of objectivity. The following citation from an article entitled "Magyar újságírók a proletárdiktatúrában" (Hungarian Journalists in the Dictatorship of the Proletariat) printed in $U_{j}^{\prime}$ Nemzedék suffices to illustrate the differences between the two sources,

In the last month of the dictatorship of the proletariat, Béla Kun's government kicked journalists hard in the stomach through its decision not to pay their salaries, as the bourgeois dailies were suspended. Journalists were supposed to teach illiterates and translate Marx, as this was the only way society could make use of them. Of the 1,700 members of the trade union of journalists only 7 "failed to heed this call" [...] After the defeat of the counter-revolution of June 24th, the executive committee of the trade union of journalists, with the support of Lajos Magyar, Ödön Pók, Andor Gábor and others, hailed for its defeat of the revolution the government that had wanted to make unemployed journalists translate Marx and teach illiterates. By this time some of the journalists had come to their senses and decided to protest against this disgraceful idea. On July 5 th they held a general 
meeting, at which some of the speakers attacked the communist government with wild enthusiasm. On the next day, on June 6th [sic!], seven journalists were dragged at gunpoint from the Otthon Circle (Homeland Circle) [...] thanks to the intervention of Romanelli, however, they were not injured. ${ }^{14}$

Lukács' reminiscences in the 1940s constitute another point of interest in the history of the reception of Kosztolányi. Writing again on the days of the communist regime of 1919, he contends,

\begin{abstract}
It is mere legend for example that during the period of counter-revolution Dezső Kosztolányi, supposedly like Mihály Babits, consistently adopted a clearly humanist standpoint. We cannot erase the era of Pardon from his biography. This period exists ineradicably, and Kosztolányi himself tried to give a psychological explanation for it in the first and last chapters of his novel, Anna Édes [...] As strongly as we may protest against the Kosztolányi legend, we must turn with equal resolve against any interpretation of his career that seeks to derive the whole of his oeuvre and literary image from the period of Pardon. Kosztolányi remains a significant poet even if he was responsible for Pardon, but this era and this frame of mind, as a trait or feature, should not be absent from his portrait. ${ }^{15}$
\end{abstract}

Yet while Lukács argues that one must not aspire to deduce Kosztolányi's lifework from Pardon (or reduce it to Pardon), he does precisely this, as does his disciple Ágnes Heller in her work published in 1957 entitled Az erkölcsi normák felbomlása. Etikai kérdések Kosztolányi Dezsö munkásságában (The Disintegration of Ethical Norms. Ethical Questions in the Oeuvre of Dezső Kosztolányi). ${ }^{16}$

The notion of clear form and pure aesthetics in art implies that art is an end itself. Art is conceptualized as free from political and social concerns, and cannot have a revolutionary role. It is no coincidence that Hungarian literary history, influenced considerably by Lukács, valued the poetry of Endre Ady over Kosztolányi, an adherent to the notion of art for art's sake. Only a few aspects of his oeuvre were interesting for Marxist theorists, among them the problems of the poor and issues of servants and maids in Anna Édes. But those problems were interpreted only from a Marxist point of view, which means that literary history characterized Anna Édes as a novel of the conflicts between social classes. Kosztolányi's reinterpreted novels and poems acquired importance, but his thoughts on aesthetics, his conceptions of language, and his translations were gradually forgotten. After the political transition of 1989 Mihály Szegedy-Maszák brought renewed attention to these questions, suggesting for instance that the gesture of translating celebrated works of the fin de siècle should not be equated with the promotion of decadence. As Szegedy-Maszák observes, 
Kosztolányi was attracted to self-reflective art from the outset. He probably had an early acquaintance with the two significant works of the aestheticism of the turn of the century, Jean-Karl Huysmans' novel A Rebours (1888) and Oscar Wilde's The Picture of Dorian Gray (1891). Both of these writings were apparently close to Kosztolányi, as he translated them in 1921 and in 1923 under the titles $A$ különc and Dorian Gray. ${ }^{17}$

But the issue of Pardon was not given analysis, even following the political transition of 1989. While dealing with Pardon we have to raise an additional thorny question: was Kosztolányi an anti-Semite? Most of Pardon articles do contain anti-Semitic arguments but one cannot in fact know exactly who authored each article, since these writings were published without reference to the author. One therefore cannot make accusations of anti-Semitism against Kosztolányi on this basis. Nevertheless, there remains a more serious problem. Literary history failed to examine or make available the sources, and rather than pursue fundamental questions merely adopted the stereotypes of Marxist ideology that found validation in canonical interpretations. Philological research and general studies about the political and historical background in an international perspective remained underdeveloped. Neither biographies nor textual editions were published. Important manuscripts disappeared from public collections or became the property of leading figures of communist cultural policy, György Aczél among them. ${ }^{18}$ They remain unavailable for research, or simply for public reading. Considering that it was possible for such events to transpire, one can hardly speak of the cultural transition that should have followed the political one. The volume of important studies edited by Geoffrey A. Hosking and George F. Cushing deals with censorship of the past decades. As they argue,

\footnotetext{
Western accounts of literature in the state socialist societies usually begin from the premise that censorship and political control there have reached an unpredecent level, with the result that to publish serious works of literature, especially those critical of the society, is virtually impossible. We then find ourselves faced with a number of exceptions to this rule. ${ }^{19}$
}

However, it was not only literary works that were censored and kept under state control, but literary histories and scholarly research as well. Hungarian intellectuals have yet to raise the question as to why open discussion of the beginning of the 20th century (which was when many of the most important events took place that continue to exert an influence on conceptions of culture) remains a taboo. Why there are no (or few) critical editions and anthologies or studies dealing with the period? Twenty years have passed since the political transition and the situation remains essentially the same. 
Kosztolányi was condemned because of his role in editing Pardon not only in reception histories, but also by some of his contemporaries. Hungarian journalist Ferenc Göndör, for example, attacked him in his paper Az Ember (Man), which was established in Vienna. Since most of the leading figures of the Commune of 1919 emigrated to Vienna, a group of Hungarian intellectuals took form that included Lukács, Lajos Kassák, Béla Balázs, Andor Gábor and Lajos Hatvany. Hatvany contributed to the establishment of Nyugat (West) and helped the career of several young talents. ${ }^{20}$ After some months Kosztolányi attempted to leave $U_{j}$ Nemzedék and tried to sell his works abroad, including in Vienna. Lajos Hatvany tried to help him, but the other emigrants refused him because of his earlier behavior. When his attempt came to light his colleagues at the daily also wanted to get rid of him. In 1921 Kosztolányi was finally able to leave Új Nemzedék and began work at Pesti Hirlap, where he was a columnist until his death. But the Pardon era taught him not to accept any political role (or role that brought him close to politics) in cultural life.

Shortly after his death the study by János Barta, published in Nyugat in $1939,{ }^{21}$ marked the first stage of the reception of Kosztolányi's oeuvre. Barta mentions irrationalism in his analysis of Kosztolányi's work. While Barta forgives him for his conduct or the pose he struck, in the later reception this pose becomes the cause of his displacement to the periphery of the canon. One of the first studies that inherited Lukács' ideas on Kosztolányi was Árpád Szabó's paper Polgári költészet - népi költészet (Bourgeois poetry - demotic poetry). ${ }^{22}$ Szabó was the pupil of Ferdinand Georg Frobenius, professor of mathematics at the University of Berlin, and he also dealt with literature and classical philology. In his rhetorically well-structured essay he points out the connections between Kosztolányi's writings and existentialism by emphasizing his cult of the self and individualism. In his conclusion he argues that Kosztolányi was a proto-fascist writer and in that sense a relative of Martin Heidegger. Zoltán Szabó replies to these arguments, writing the following: "the sober mind cannot grasp why it would be necessary to execute someone whose body is dead but whose spirit is immortal." ${ }^{23}$ Árpád Szabó begins by analyzing the changes that took place in Hungarian society at the turn of the 20th century. Adopting a standpoint that is in contradiction with the idea of art for art's sake, he poses the question of the close connections between literature and politics. In his opinion Ady was the only writer who broke out from aesthetism and tried to represent the revolutionary artist. It is not difficult to conclude that the origins of Ady's and Kosztolányi's place in the Hungarian literary canon under communism lie not only with Lukács but also Szabó. But one could also mention the discussion of Ady, when even Kosztolányi's contemporaries turned against him, since he attacked the memory of Ady in 1929 in an article that was pubished in $A$ Toll (The Plume). Sándor Petőfi is also mentioned alongside Szabó, and named as a revolutionary poet. These key issues (the attack against 
Ady, his conduct during the White Terror, and his belief in the idea of art for art's sake) create the main stream of the reception of Kosztolányi under communism. That fact clearly shows the connections between politics and literature, or at the very least the relationship between literary studies and the ideologies of the dominant classes. The figure of Kosztolányi becomes a kind of Satan in that context. In Lukács's words, he was a "conscious and malicious" 24 person who constituted a danger to communist society, and those who wish to pursue research on his work were also dangerous enemies of the communist system. In order to smirch Kosztolányi's reputation further, Szabó cites Gyilkosok(Killers), one of his early poems,

These lines speak so clearly that any commentary would be superfluous. The author assumes unqualified solidarity with the 'glorious force' - the killers - since the rule of law that smites them, the heinous Themis, is only a 'painted whore' $[\ldots]^{25}$

Like Ágnes Heller, Szabó also mixes biographical data with literary texts and draws essentially ethical conclusions from the bizarre miscellany. Due to their works, which are based on the ideas of Lukács, Kosztolányi was pushed out from the canon for decades. Heller also identifies what she characterizes as the journalist's moral (or rather immoral) attachment to decadent bourgeois society. The starting argument of her book is that as a journalist Kosztolányi was unprincipled and immoral, and this behavior can be discerned in his literary texts as well.

\section{A journalist can only be saved from the bourgeois journalist moral by one thing: a consistent ideological attitude of mind. And only a con- sistent political attitude can create a consistent ideological attitude. ${ }^{26}$}

Kosztolányi's thoughts on relativity become dangerous for the communist moral, since he forgot that according to communist ideology the role of art is to educate the nation and address questions of ethics. As there are numerous of nihilistic and ill-willed figures in his writings (Kornél Esti behaves like an anarchist sometimes, for example), Kosztolányi becomes a symbol of nihilism and his ars poetica a destructive way of thinking.

One might think that after the political transition of 1989 no one continued the tradition represented by Heller's book, but there are on the contrary several examples. These include László Márton, who also adopts the terms of the Marxist ethics. He does not speak directly from a Marxist point of view, but nonetheless raises moral questions when writing on Kosztolányi. He also mentions the Ady discussion and the case of the Pardon articles as well. By analyzing texts of letters and diaries, he comes to the following conclusion:

Whatever the case, we are not speaking here of the destruction of moral norms (as a study written 40 years ago attempted to demon- 
strate), because this existed since Mikszáth, or even in the age of reforms, which was so richly gilded in virtue, in the work of Lajos Kuthy, and for this there is no need of all the linguistic-stylistic and role-switching bravura that Kosztolányi produces. These changes could rather be interpreted as a kind of inborn 'prank of character'. It is a demonic feature of personality, a Prothean variability. ${ }^{27}$

Mihály Szegedy-Maszák gives a reply to those who would like to base interpretations of letters and diaries on the supposed dark side of the author's personality. He mentions Nietzsche, who had a considerable influence on Kosztolányi, ${ }^{28}$ and notes that after the emergence of the German philosopher thoughts on moral values (since we are beyond good and evil) became problematic and notions of relativism acquired new significance. Given this Szegedy-Maszák's perspective could be thought of as more current than Márton's, but one might still raise the question as to whether relativism represents the final stage in human intellectual development. I would contend that the discernment of unity and harmony becomes more and more important both in common philosophy and in everyday life. Postmodern philosophers who promulgated the fragmentation and disintegration of the self reached a dead end.

András Lengyel also speaks about the influence of Nietzsche and correlates it with the problems of personality. He also mentions the poem Gyilkosok (Killers) and the anarchism of Kornél Esti. As he argues in his study,

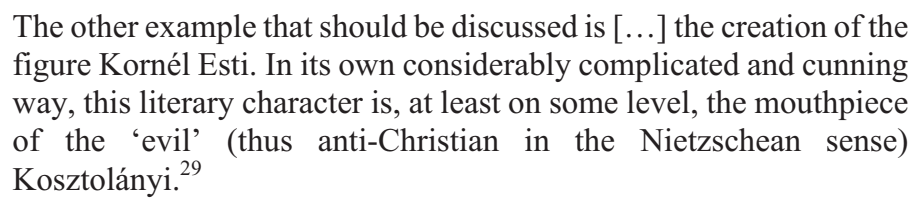

In the course of time Kosztolányi’s oeuvre became part of the canon. Marxist interpretators put the emphasis on his humanity and compassion with the poor. Pál Réz, who edited the series of the works of Dezső Kosztolányi, also notes his humanity, but does not neglect to mention the notion of art for art's sake. He also addresses the articles written in Pardon, but he does not pass judgment on Kosztolányi because of them, as one cannot know which of the articles he wrote. As he writes in one of his essays,

But we also know that he edited the arrant heading Pardon of $U_{j} j$ Nemzedék. According to the recollections of his contemporaries, articles in that column were written by four people: Miklós Kállay, István Lendvai, Father Béla Bangha, and Dezső Kosztolányi. Shameful articles were published in the column of that clerical, extreme nationalist, provocative daily. These articles make denunciations, issues calls for revenge, and demand that writers and artists remain silent. Journalists, fortunately, did not sign their articles and at 


\begin{abstract}
the moment it is not possible to determine who authored which horrible piece of writing. We use the word fortunately, and the word surely seems frivolous and absurd coming from the plume of a literary historian or philologist. But Kosztolányi is one of my favorite writers. This is why I am happy that we do not find his name under those petty and forbiddingly accusing articles. ${ }^{30}$
\end{abstract}

Since Réz worked during the communist era, he was unable to publish all of Kosztolányi's texts, and even though he did publish some that had a bearing on the contemporary political context, he was only able to do so under censorship. We can quote some documents here that demonstrate the pressure that he was under as an editor. Zoltán Héra, who was a celebrated cultural politician of the period and vice leader of the column Culture at Népszabadság (Freedom of the People), one of the main dailies, attacked Réz's afterword to one of the Kosztolányi volumes. As he argues in his review of the book in 1958 (in other words after the Revolution of 1956, at the time when people were being punished for participation in the events of the Revolution),

\begin{abstract}
Kosztolányi's essays are quite 'ideological' after all. There was no more militant propagator or vigilant defender of the bourgeois notion of art for art's sake [...] He [Pál Réz, the author of the afterword] does not realize that Kosztolányi was on the side of bourgeois 'pure art' at the time when he wrote on Móricz or Lajos Nagy [...] Well, Kosztolányi was a far too 'writerly' for there to have been a chasm separating his feelings and thoughts. Principle and ideology were not abstract theories for him, they pervaded his instincts, his whole nervous system. It was reflex and routine. ${ }^{31}$
\end{abstract}

There was another tendency in the later Marxist interpretations. Like Héra, Sándor Koczkás also wanted to point out that Kosztolányi was a bourgeois who would have liked to promote bourgeois literature and ideologies that relate to that social system. Instead of branding him a person without principles, he characterized Kosztolányi as a conscious destroyer and enemy of communism. Sándor Koczkás, a one-time professor at Eötvös Loránd University in Budapest, analyzed Kosztolányi's philosophy of art for art's sake: "the thing for which people - for which we - most often criticized him, his facilely elegant lack of principles, was really only an effective mask covering his carefully thought-out principled standpoint". ${ }^{32}$ Koczkás also mentions that Kosztolányi became a kind of symbol or an ideal of bourgeois ambitions for groups that were against communism. Considering the circumstances, it is no wonder there is still no critical edition of Kosztolányi's works.

During the 1990s postmodern theoretists discovered his oeuvre and analyzed his works almost exclusively from the point of view of narratology. A number of new readings were published and his theories on language also came to focus. As 
one of the leading figures of the Kosztolányi renaissance, Mihály SzegedyMaszák argues,

His view of language markedly differs from that of Hegel or Saussure, who believed that the connection between signifier and signified is arbitrary, and has more in common with that of Heidegger, decipherer of words, or Derrida, who rejected the familiar meaning by right of signifier. ${ }^{33}$

It is not coincidental that after the political transition of 1989 works came out to light that had been forgotten or censored. Applying the recent ideas of postmodern philosophy and literary theory, including hermeneutics, deconstruction and other trends, readers of Kosztolányi's oeuvre were able to reinterpret numerous questions, among them the case of Kornél Esti, the character, the genre, and its connections with the author's thoughts on the nature of language. ${ }^{34}$

Nevertheless there are some important questions that have not yet been answered. As mentioned above, questions concerning the articles in Pardon remain unanswered. Furthermore, there is little new philological research, and only one bibliography has been published (and it contains only a small part of the oeuvre as the first volume of the whole bibliography). ${ }^{35}$ There is no authentic biography and the critical edition project, which began only two years ago, has had to face difficult questions concerning Kosztolányi's lifework. Hungarian philologists who deal with Kosztolányi's oeuvre must address these questions and challenge the Marxist axioms and stereotypes if they hope to further the development of Kosztolányi's reception. Relying on postmodern theories is not sufficient if there is little fundamental research.

\section{Notes}

Zagorin, Perez (1980) 'Preface' in Perez Zagorin (ed.): Culture and Politics From Puritanism to the Enlightenment (Berkeley-Los Angeles-London: University of California Press). ix.

2 "Az írástudók általános feladata más: ébren tartani, tudatosítani a magyar nemzeti élet igazi kérdéseit, megkeresni és megtalálni rájuk a progresszív válaszokat. Ennek a nagy feladatnak teljesítése határozza meg az írástudók felelősségét." - Lukács, György (1945) ‘Előszó' (Foreword) in Írástudók felelössége (Budapest: Szikra). 17.

3 “A Tanácsköztársaság idején írt cikkeiben csupán a morális tisztulás és a kulturális felemelkedés lehetőségének megteremtését látja a forradalomban; azt hirdeti ekkor, hogy a »politika csak eszköz, a kultúra a cél«. Csatlakozása a kommunistákhoz eleinte tehát nem jelentette a megváltó tan megtalálását, az ideológiai elkötelezést. [...] Lukács György 1918 késő őszén [...] csak politikai fordulatot tett.” - Hanák, Tibor (1974) A filozófus Lukács (The philosopher Lukács) (Paris: Magyar Mühely). 7, 65.

4 De Man, Paul (1971) 'George Lukács's Theory of the Novel” in Blindness and Insight. Essays in the Rhetoric of Contemporary Criticism (Oxford: Oxford University Press). 52. 
5 "Christian and national ideology and the political aims of the government were served by the media of several trends. The Jesuit preacher and politician Béla Bangha was the first who brought out Catholic and radical point of view and who started a number of dailies from September 1919, for rolling back the »destructive Jewish media«. These journals were the following: Új Nemzedék (1919-1944, earlier it was a weekly), Nemzeti Újság that inherited the position of Alkotmány (1919-1944) Új Lap, the literary and political periodical Gondolat and the the magazine Képes Krónika. At that time had begun functioning the Központi Sajtóvállalat (Central Media Company) as well. During the 1930s the company needed regular financial support - the amount exceeded 200,000 pengős (Hungarian currency of that period) per year -, although Uj Nemzedék was one of the leading dailies at that age with its 77,000 issues." ("A keresztény nemzeti eszmerendszert és a kormányzati célokat több, különböző áramlat sajtója szolgálta. A katolikus radikális álláspontot elsőként Bangha Béla jezsuita hitszónok és politikus szólaltatta meg, aki a »destruktív zsidó sajtó« háttérbe szorítására számos lapot indított 1919 szeptemberétől: az Új Nemzedék (1919-1944, korábban hetilap), az Alkotmány örökébe lépő Nemzeti Újság (1919-1944) és az Új Lap címủ napilapokat, a Gondolat című irodalmi és politikai folyóiratot és a Képes Krónika című képeslapot. Ekkor kezdett el múködni az általa alapított Központi Sajtóvállalat is. Ez a harmincas években rendszeres támogatásra szorult - évi mértéke meghaladta a kétszázezer pengőt -, bár a 77,000 példányban megjelenő Új Nemzedék például a korszak kiemelkedően nagy lapjai közé tartozott.") Kókay, György - Buzinkay, Géza - Murányi, Gábor (eds) (1998) A magyar sajtó története (History of Hungarian Media) (Budapest: MÚOSZ). 184.

6 Besides Lukács Zsigmond Kunfi, Sándor Szabados and Tibor Szamuely were ministers of education during the Commune of 1919.

7 Kosztolányi, Dezső (1919) “Beer úr' (Sir Beer), Pesti Napló, May 8th, 1.

8 “A sajtó és Lukács, illetve a Közoktatásügyi Népbiztosság közötti konfliktusok történetéhez tartozik a népbiztosságnak az a korábbi belső rendelete, amely előírta, hogy a volt polgári lapok vezércikkeit aláírva kell közölni. A május elején hozott rendeletet Göndör Ferenc Vallomások könyve címü visszaemlékezése Lukácsnak tulajdonítja. A Tanácsköztársaság sajtójában csak egy helyütt történik rá utalás, a Vörös Újság május 9-i vezércikkében, amelyet, ugyancsak Göndör Ferenc visszaemlékezése szerint, Hajdu Pál írt. [...] A cikk élesen támadta »az osztály feletti osztállyá fajult újságírók henye kasztját«. E támadás kiváltó oka az volt, hogy a polgári sajtóban megjelent néhány cikk nacionalista hangvételben kommentálta a Tanácsköztársaság ellen irányuló katonai, illetőleg gazdasági lépéseket, ami visszatetszést szült a kommunista vezetőkben. (A kifogásolt cikkek közé tartozott Kosztolányi Dezső Beer úr címü, a Pesti Napló május 8-i számában megjelent vezércikke [...])”-Mesterházi, Miklós (1987) 'Jegyzetek' (Notes) in György Lukács (1987) Forradalomban. Cikkek, tanulmányok 1918-1919 (Budapest: Magvetö). 534.

9 About the media law and the question of the media during the Commune of 1919, see: KókayBuzinkay - Murányi (1998) Ibid., 178-179.

10 Cushing, George F. (1989) 'Social Criticism in Hungarian Literature since 1956' in Geoffrey A. Hosking and George F. Cushing (eds) Perspectives on Literature and Society in Eastern and Western Europe (London: Macmillan Press). 103.

11 "Lukács azonban közvetlenül az 1934-es önkritikája után sem fordított hátat a Hegelproblémának. 1938-ban már elkészült a német idealista filozófus ifjúkorával foglalkozó művének kézirata, melyet azonban a Szovjetunióban uralkodó hivatalos felfogások következtében nem publikálhatott. [...] Szerinte [ti. Lukács] a marxi dialektika keletkezéstörténetéhez elszakíthatatlanul hozzátartozik Hegel szellemi fejlődésének vizsgálata, az idealista dialektika kialakulásának nyomon követése.” - Hanák, Tibor (1974) Ibid., 65-66. 
12 “Kosztolányi Dezső [...] az egyetlen lírikus Ady Endre fellépése óta, aki komolyan tekintetbe jöhet, és az egyetlen Ady mellett, akivel érdemes foglalkozni. [...] Ady Endre a harcos kultúrmagyarság költője volt; Kosztolányi esztéta. [...] Kosztolányi jelentősége az, hogy meglátja mindazt, amit festőink közül a kevés legjobb meglát, és hogy sokszor szavakat tud találni számukra. Ha még egypáran lennének, akik olyan intenzív erővel keresik az új magyar nyelvet, mint ő, tíz év múlva mindent meg lehetne írni magyarul is.” - Lukács, György (1977) 'Négy fal között. Kosztolányi Dezső versei' (Between four walls. Poems of Dezső Kosztolányi) in Árpád Tímár (ed.) Ifjúkori müvek 1902-1918 (Budapest: Magvető). 117-118.

13 “A Diktatúrában is hatott Mikszáthnak az a gondolata: »Mutass nekem egy olyan kormányt, amelyet én nem fogok támogatni.« Hogy más példára ne is hivatkozzam, Kosztolányi Dezső felajánlotta, hogy munkaközösséget szervez Marx Tőkéjének lefordítására. Nem arról volt szó, hogy Kosztolányit erre bárki is kényszerítette volna, sőt ellenkezőleg, alig lehetett tervéről lebeszélni. [...] Semmiféle idealizálás kedvéért nem szabad kihagyni a Diktatúra történetéből, hogy olyan emberek, mint Kosztolányi, tömegével jelentkeztek. Itt nekem az volt az álláspontom, hogy pillanatra sem vettem komolyan Kosztolányi elhatározását, de nevetségesnek tartottam volna, ha a Diktatúra ezeket a lehetőségeket nem használja ki. Utólag beszéltek az emberek kényszerről. Még Kassák is megtette ezt a későbbi időkben, amikor hízelegni kívánt a jobboldali szociáldemokratáknak.” - Lukács, György (1970) ‘Bartók és a magyar forradalom' (Bartók and the Hungarian Revolution) in Magyar irodalom - magyar kultúra. Válogatott tanulmányok (Budapest: Gondolat). 651.

14 “A proletárdiktatúra utolsó hónapjában Kun Béla kormánya hatalmas rúgást mért a szolgamódon meglapuló újságírók gyomrába és elhatározta, hogy nem fizeti többé őket, mert hiszen a polgári lapok szünetelnek. Az újságíró menjen analfabétát tanítani és Marxot fordítani, mert különben nem veheti hasznát a társadalom. Ennek a felszólításnak 1,700 újságíró szakszervezeti tag közül csak 7-en nem tettek eleget [...]. A június 24-i ellenforradalom leverése után az újságírók szakszervezetének végrehajtóbizottsága: Magyar Lajos, Pók Ödön, Gábor Andor és mások támogatásával kimondotta, hogy a forradalom leverésének magasztos tényéért üdvözli azt a kormányt, amely Marxot akar fordíttatni és analfabétákat akar oktattatni az állástalan újságírókkal. Ekkor már észhez kapott az újságírók egy töredéke és elhatározta, hogy valamilyen formában tiltakozik ez ellen a gyalázatos szándék ellen. Július 5-én közgyülést tartottak, amelyen néhány szónok váratlan hevességgel támadta meg a tanácskormányt. Másnap, június 6-án [sic!] hét újságírót szuronyok között hurcoltak el az Otthonkörböl... azonban Romanelli közbelépésére nem történt komolyabb bajuk." - Lenz, Géza [Riporter] (1919) 'Magyar újságírók a proletárdiktatúrában' (Hungarian journalists under the communist dictatorship), Új Nemzedék, September 15th, 15.

15 "Legenda például az, hogy az ellenforradalmi korszakban Kosztolányi Dezső, állítólag éppen úgy, mint Babits Mihály, mindig tiszta humanista álláspontot foglalt el. Nem lehet Kosztolányi életéből a Pardon-rovat korszakát kiradírozni. Ez a korszak kitörölhetetlenül létezik és maga Kosztolányi próbál rá lélektani magyarázatot adni az Édes Anna bevezetésében és befejezésében. [...] Amilyen élesen tiltakozunk a Kosztolányi-legenda ellen, olyan élesen kell szembefordulni minden olyan felfogással, mely a Pardon-rovatból akarja »levezetni« Kosztolányi egész életművét és írói egyéniségét. Kosztolányi jelentékeny költő annak ellenére, hogy a Pardon-rovatot csinálta, de ennek az időnek, ennek az állásfoglalásnak, ennek a magatartásnak - mint vonásnak - nem szabad hiányoznia írói arcképéből.” - Lukács, György (1970) 'Régi és új legendák ellen' (Against old and new legends), in Magyar irodalom - magyar kultúra. Válogatott tanulmányok (Budapest: Gondolat). 411-412.

16 Heller, Ágnes (1957) Az erkölcsi normák felbomlása. Etikai kérdések Kosztolányi Dezsö munkásságában (The Disintegration of Ethical Norms. Ethical Questions in the Oeuvre of Dezső Kosztolányi), (Budapest: Kossuth). 
17 “Kosztolányi kezdettől fogva vonzódott az öntükröző művészethez. Valószínűleg korán megismerte a századvég esztétizmusának két jellegzetes alkotását, Jean-Karl Huysmans $A$ Rebours (1888) és Oscar Wilde The Picture of Dorian Gray (1891) című regényét. Mindkét mủ nyilvánvalóan közel állt Kosztolányihoz, hiszen utóbb, 1921-ben illetve 1923-ban az ő fordításában jelentek meg magyarul, A különc illetve Dorian Gray arcképe címmel." Szegedy-Maszák, Mihály (1998) 'Kései müvek előképe. Kosztolányi: A cseh trombitás' (Prefigurations of later works. Kosztolányi: The Bohemian Trumpeter) in Irodalmi kánonok (Debrecen: Csokonai). 141.

18 See: Bíró-Balogh, Tamás (2008) 'Előkerült Kosztolányi utolsó verse' (Kosztolányi’s last poem has turned up), http://www.litera.hu/hirek/elokerult-kosztolanyi-utolso-verse

19 Hosking, Geoffrey A. (1989) 'Introduction', in Geoffrey A. Hosking and George F. Cushing (eds) Perspectives on Literature and Society in Eastern and Western Europe (London: Macmillan Press). 1.

20 Some of the remarkable articles are: Göndör, Ferenc (1921) 'Dezső, ne hazudj!' (Dezső do not lie!), Az Ember, May 15th, 6-7; Göndör, Ferenc (1921) ‘Egy szegény kis ember panaszai’ (Laments of a little poor man), Az Ember, June 26th, 10; g. f. [= Ferenc Göndör] (1921) 'Megdöglött a kurzus! Avagy: Kádár Lehel, Lendvai (Lehner), Kosztolányi, Szabó Dezső, Krüger Aladár, a Miklós Andor rituális ravatalán’ (The course died, or: Lehel Kádár, Lendvai /Lehner/, Kosztolányi, Dezső Szabó, Aladár Krüger are on the ritualistic catafalque of Andor Miklós), Az Ember, October 9th, 4-5; Gábor, Andor (1921) 'Dezső lehazudja a csillagokat' (Dezső Tells Nothing but Lies), Bécsi Magyar Újság, May 10th, 6.

21 Barta, János (1939) 'Kosztolányi költői hagyatéka. Szeptemberi áhitat. Révai’ (Poetic heritage of Kosztolányi. Devotion of September. Révai), Nyugat, Vol. 5, 331.

22 Szabó, Árpád (1946) 'Polgári költészet - népi költészet. 1. Kosztolányi' (Bourgeois poetry demotic poetry. 1. Kosztolányi), Valóság, Vol. 11, 1-24.

23 “... józan ésszel nem lehet megérteni, hogy minek kivégezni azt, aki testi mivoltában halott, szellemi mivoltában halhatatlan.” - Szabó, Zoltán (1947) ‘Kézmozdulat és vélemény’ (Pass and opinion), Valóság, Vol. 2, 126.

24 Lukács, György (1945) Írástudók felelőssége (Responsibility of literates) (Budapest: Szikra). 11.

25 "Ezek a sorok olyan világosan beszélnek, hogy szinte fölösleges minden kommentár. Az író fenntartás nélkül vállalja a szolidaritást a »dicső erővel«, a gyilkosokkal, mert hiszen az a jogrend, amely a gyilkosokat sújtja, az undok Themis, úgyis csak »festett szajha«..." - Quotes: Szabó, Árpád (1946) Ibid., 11.

26 "Újságírót a polgári újságíró moráltól csak egyetlen dolog mentheti meg: a szilárd világnézeti állásfoglalás. Szilárd világnézetet egyedül a szilárd politikai állásfoglalás teremthet meg." Heller, Ágnes (1957) Ibid., 21.

27 "Bárhogy van is, nem az erkölcsi normák felbomlásáról van itt szó (amit egy negyven évvel ezelőtti tanulmány próbált kimutatni), mert az már megvolt Mikszáthnál, sőt már az erényektől oly vastagon bearanyozott reformkorban, Kuthy Lajosnál is megvolt, s ahhoz nem kell annyi nyelvi-stilisztikai és szerepváltásbeli bravúr, mint amennyit K. D. produkál; e váltásokat inkább valamiféle természet adta »jellemcsínynek« lehet tekinteni. A jellem egyik démoni vonása ez, próteuszi változékonyság.” - Márton, László (1997) ‘Színes tinták bölcsessége’ (Wisdom of coloured inks), Holmi, Vol. 9, 1322.

28 Szegedy-Maszák, Mihály (1998) ‘A kánonok hiábavalósága. Kosztolányi a világirodalomról’ (Vanity of canons. Kosztolányi on world literature) in Irodalmi kánonok (Debrecen: Csokonai). 46.

29 “A másik példa, amely e beállítódás következményei között tárgyalható, Esti Kornél [...] figurájának megteremtése. A maga meglehetősen bonyolult és rafinált módján ez az irodalmi 
figura - legalábbis egy síkon - a »gonosz« (tehát nietzschei értelemben vett antikeresztény) Kosztolányi szócsöve.” - Lengyel, András (2000) ‘Csillogó felületek gyöngyhalásza. Kosztolányi Dezső nietzschei vázgondolatai’ (Pearl fisher of glittering surfaces. Kosztolányi’s Basic Thoughts, Derived from the Ideas of Nietzsche), in Játék és valóság közt. Kosztolányitanulmányok (Szeged: Tiszatáj). 85.

30 "De tudjuk azt is, hogy ő szerkesztette az Új Nemzedék hírhedt Pardon rovatát. A rovat cikkeit a kortársak emlékezete szerint négyen írták: Kállay Miklós, Lendvai István, Bangha Béla páter - és Kosztolányi Dezső. A klerikális, szélsőségesen nacionalista, uszító lapnak ebben a rovatában szégyenletes cikkek jelennek meg: denunciálnak, bosszúért kiáltanak, írók és művészek elhallgattatását követelik. A hírlapírók, szerencsére, nem jegyezték a cikkeiket, s ma már nem áll módunkban megállapítani, hogy melyik förmedvénynek ki a szerzője. Szerencsére, mondtuk, s a szó bizonyára léhának és képtelennek tűnik fel irodalomtörténész és filológus tollán. De Kosztolányi a legkedvesebb íróim közé tartozik; ezért veszem szívesen, hogy a kisszerúen, de fenyegetőn vádaskodó cikkek alatt nincs ott a neve." - Réz, Pál (1973) 'Kosztolányi, a hírlapíró’ (Kosztolányi, the journalist) in Kulcsok és kérdőjelek (Budapest: Magvető). 100.

"Nos, Kosztolányi kritikai írásai nagyon is »világnézetiek«. A polgári l'art pour l'art-nak nem volt nálunk harcosabb propagátora, éberebb védelmezője. [...] Nem veszi észre, hogy Kosztolányi a polgári 'tiszta művészet' posztján állott akkor is, amikor Móriczról vagy Nagy Lajosról írt. [...] Nos, Kosztolányi sokkal »íróbb« író volt annál, semhogy hangulat és gondolat közt őnála szakadék legyen. Elv és világnézet nem elvont teória volt az ő számára - átjárta az ösztöneit, egész idegrendszerét, reflex volt már és rutin.” - Héra, Zoltán (1958) ‘Részrehajlás, vagy elfogulatlanság? Megjegyzések egy utószóhoz’ (Favour or candour? Notes to an afterword), Népszabadság, December 25th, 19.

32 "S amit talán legtöbbször vetettek, vetettünk szemére: könnyeden elegáns elvtelenségét valójában határozottan végiggondolt elvi álláspont hatásos álarca csupán." - Koczkás, Sándor (1958) "A kritika elefántcsonttornya" (Ivory tower of criticism), Valóság, Vol. 4, 37.

33 "Nyelvszemlélete erősen különbözik Hegel vagy Saussure felfogásától, akik önkényesnek vélték a kapcsolatot jelentő és jelentett között, és inkább rokon a szófejtő Heidegger vagy akár a megszokott jelentést a jelentő alapján kitörlő Derrida álláspontjával.” - Szegedy-Maszák, Mihály (1995) 'Kosztolányi nyelvszemlélete' (Kosztolányi’s view of language) in Minta a szőnyegen. A müértelmezés esélyei (Budapest: Balassi). 170.

34 See: Kulcsár Szabó, Ernő and Mihály Szegedy-Maszák (eds) (1998) Újraolvasó (Rereader) (Budapest: Anonymus). 7.

35 Arany, Zsuzsanna (ed.) (2008) Kosztolányi Dezsö napilapokban és folyóiratokban megjelent irásainak jegyzéke 1 (Bibliography of Kosztolányi's writing published in dailies and periodicals 1) (Budapest: Ráció). 